\title{
Design and Implementation of a C02 Flood Utilizing Advanced Reservoir Characterization and Horizontal Injection Wells in a Shallow Shelf Carbonate Approaching Waterflood Depletion
}

\author{
Quarterly Report \\ January 1 - March 31, 1998 \\ By \\ Kimberly B. Dollens; J. Scott Bles
}

Work Performed Under Contract No.: DE-FC22-94BC14991

For

U.S. Department of Energy

Office of Fossil Energy

Federal Energy Technology Center

P.O. Box 880

Morgantown, West Virginia 26507-0880

By

Phillips Petroleum Company

4001 Penbrook Street

Odessa, Texas 79762 


\section{Disclaimer}

This report was prepared as an account of work sponsored by an agency of the United States Government. Neither the United States Government nor any agency thereof, nor any of their employees, makes any warranty, express or implied, or assumes any legal liability or responsibility for the accuracy, completeness, or usefulness of any information, apparatus, product, or process disclosed, or represents that its use would not infringe privately owned rights. Reference herein to any specific commercial product, process, or service by trade

name, trademark, manufacturer, or otherwise does not necessarily constitute or imply its endorsement, recommendation, or favoring by the United States Government or any agency thereof. The views and opinions of authors expressed herein do not necessarily state or reflect those of the United States Government or any agency thereof. 
Design and Implementation of a CO2 Flood Utilizing Advanced Reservoir Characterization and Horizontal Injection Wells in a Shallow Shelf Carbonate Approaching Waterflood Depletion

Quarterly Technical Report

Reporting Period: Start Date:01/01/1998 End Date: 03/31/1998

Authors:

Kimberly B. Dollens

J. Scott Bles

Report Issue Date: 04/28/1998

DE-FC22-94BC14991--17

Phillips Petroleum Company

4001 Penbrook Street

Odessa, Texas 79762 
DESIGN AND IMPLEMENTATION OF A CO2 FLOOD UTILIZING ADVANCED RESERVOIR CHARACTERIZATION AND HORIZONTAL INJECTION WELLS IN A SHALLOW SHELF CARBONATE APPROACHING WATERFLOOD DEPLETION

Cooperative Agreement Number:

Contractor Name and Address:

Date of Report:

Award Date:

Anticipated Completion Date:

Government Award for 1997 Fiscal Year:

Project Director:

DOE Project Officer:

Reporting Period:
DE-FC22-94BC14991

Phillips Petroleum Company 4001 Penbrook Street

Odessa, Texas 79762

April 28, 1998

June 3, 1994

January 2, 2001

$\$ 1,379,607$

Kirk Czirr

Jerry F. Casteel

Jan. 1, 1998 - Mar. 31, 1998 


\section{LEGAL NOTICE / DISCLAIMER}

This report was prepared by Phillips Petroleum Company as an account of work sponsored by an agency of the United States Government. Neither the United States Government nor any agency thereof, nor any of their employees, makes any warranty, express or implied, or assumes any legal liability or responsibility for the accuracy, completeness, or usefulness of any information, apparatus, product, or process disclosed, or represents that its use would not infringe privately owned rights. Reference herein to any specific commercial product, process, or service by trade name, trademark, manufacturer, or otherwise does not necessarily constitute or imply its endorsement, recommendation, or favoring by the United States Government or any agency thereof. The views and opinions of authors expressed herein do not necessarily state or reflect those of the United States Government or any agency thereof. 


\section{OBJECTIVE}

The first project objective is to utilize reservoir characterization and advanced technologies to optimize the design of a carbon dioxide $\left(\mathrm{CO}_{2}\right)$ project for the South Cowden Unit (SCU) located in Ector County, Texas. The SCU is a mature, relatively small, shallow shelf carbonate unit nearing waterflood depletion. The second project objective is to demonstrate the performance and economic viability of the project in the field. All work during the fourth quarter falls within the demonstration project.

\section{SUMMARY OF TECHNICAL PROGRESS}

\section{BUDGET PHASE II}

\section{TASK V FIELD DEMONSTRATION}

\section{Reduce Reservoir Pressure (not included in DOE funding)}

Subtask V.1.9 of the Revised Statement of Work included funds for the deepening of water injection wells inside the Unit boundary as necessary to handle the increased water injection capacity. However, this Subtask was specifically excluded from funding by the DOE.

During March, 1997, the project team requested funds to deepen, complete and equip South Cowden Unit (SCU) Well No. 2-18 for use as a water disposal well for the South Cowden Unit $\mathrm{CO}_{2}$ project. Recent shut-in bottomhole pressure data in the DOE Project Area indicate the reservoir pressure to be approximately $2300 \mathrm{psig}$ in the SCU, increasing to approximately 2600 psig in the Emmons Unit to the immediate north. Bottom-hole pressure surveys run on the horizontal injection Wells Nos. 6C-25H and 7C-11H, on February 3, 1998, indicated 2614 psig and 2632 psig @ reservoir datum of -1700 (4651 TVD). The minimum miscibility pressure (MMP) for the $\mathrm{CO}_{2}$ project is only $1200 \mathrm{psig}$; therefore, significant margin exists above the MMP in which to work. In fact, the optimum reservoir pressure for $\mathrm{CO}_{2}$ flooding is estimated at closer to $1800 \mathrm{psig}$, as lower pressures would allow the injected $\mathrm{CO}_{2}$ to occupy more reservoir volume and contact more recoverable oil. The Project team is in unanimous agreement that disposal of water in a lower San Andres interval would ultimately increase the overall San Andres system pressure, thus further contributing to the problem. Thus, the above-mentioned project was recommended as an alternative to Subtask V.1.9 of Phase II of the South Cowden Unit DOE Project.

Approximately 8000 BWPD are currently being produced in the Unit, and are being reinjected. As $\mathrm{CO}_{2}$ injection continues, the reservoir will necessarily continue to pressure-up, further decreasing the efficiency of the $\mathrm{CO}_{2}$ in the reservoir. Funds were requested to deepen the plugged and abandoned SCU Well No. 2-18 to the Canyon at 9880', for disposal of up to 5000 BWPD outside the San Andres $\mathrm{CO}_{2}$ target interval. This would allow for the reduction of reservoir pressure within the Project Area, thus increasing the efficiency of the $\mathrm{CO}_{2}$ in the reservoir and perhaps increasing the narrow pressure margin between the fracture gradient and 
reservoir pressure. The identified out-of-zone injection problems are recognized to be primarily the result of injection at or above the reservoir parting pressure.

This work is premised to commence in July, 1998, with initial injection during August, 1998.

\section{Increase Throughput}

A new chemical treatment was tested on SCU Well No. 7-08 on March 5, 1998. The system was designed to address paraffin/asphaltenes, calcium carbonate, and calcium sulfate in a single application. The expense work included a paraffin/asphaltene solvent, sulfate and carbonate remover, antisludge chemicals, and an iron reducing agent. The job was applied via the casingtubing annulus.

The well showed no increase in oil production following the treatment, but daily water production increased by over 100 BWPD.

\section{Purchase $\mathrm{CO}_{2}$ and Operation of Recycle Compression Facilities}

The $\mathrm{CO}_{2}$ recycle compression facilities have been in continuous operation during first quarter, 1998.

Gas injection volumes for the four SCU injection well and the three cooperative leaseline injection wells for the last 12-month period are reported below. These volumes have been updated and corrected from previous reports,

\section{GAS INJECTION}

$\begin{array}{lcccccr} & \text { Apr 97 } & \text { May 97 } & \text { Jun 97 } & \text { Jul 97 } & \text { Aug 97 } & \text { Sep 97 } \\ & & & & & & \\ \text { Monthly -mcf } & 246,126 & 243,854 & 290,464 & 309,884 & 255,958 & 157,118 \\ \text { Daily Average-mcfpd } & 8,204 & 7,866 & 9,682 & 9.995 & 8,257 & 5,237 \\ \text { Cumulative-mcf } & 2,098,967 & 2,342,821 & 2,633,285 & 2,943,129 & 3,199,087 & 3,356,205\end{array}$

Oct 97 Nov $97 \quad$ Dec $97 \quad$ Jan $98 \quad$ Feb $98 \quad$ Mar 98

$\begin{array}{lrrrrrr}\text { Monthly -mcf } & 295,130 & 312,344 & 181,053 & 174,565 & 148,969 & 152,456 \\ \text { Daily Average-mcfpd } & 9,520 & 10,411 & 5,840 & 5,631 & 5,320 & 4.918 \\ \text { Cumulative-mcf } & 3,651,335 & 3,963,679 & 4,144,732 & 4,319,297 & 4,468,2664,620,722\end{array}$

\section{$\underline{\text { Unit Production }}$}

By late December, sustained oil production had increased approximately 150 barrels of oil per day (BOPD) total, with 75 BOPD as a result of the $\mathrm{CO}_{2}$ injection in the near vicinity of the horizontal injection wells, and the remaining 75 BOPD as a result of the earlier stimulation program. The 
production in the following quarter has been declining primarily as a result of decreased $\mathrm{CO}_{2}$ injection, as the reservoir pressure will begin to level-out and decline. A summary of quarterly average production and injection follows:

\begin{tabular}{|c|c|c|c|c|c|}
\hline \multirow[b]{2}{*}{ Qtr } & \multicolumn{3}{|c|}{-------PRODUCTION------- } & \multicolumn{2}{|c|}{--------INJECTION----.- } \\
\hline & BOPD & BWPD & MCFD & BWIPD & MSCFPD CQ \\
\hline 1st 1996 & 375 & 3861 & 88 & 4520 & 0 \\
\hline 2nd 1996 & 356 & 3526 & 89 & 4208 & 0 \\
\hline 3rd 1996 & 337 & 4301 & 91 & 4144 & 3623 \\
\hline 4th 1996 & 375 & 4907 & 105 & 4900 & 8674 \\
\hline 1st 1997 & 442 & 5837 & 611 & 5837 & 8111 \\
\hline 2nd 1997 & 425 & 6462 & 929 & 6462 & 8576 \\
\hline 3rd 1997 & 445 & 6408 & 1110 & 6834 & 7858 \\
\hline 4th 1997 & 485 & 8003 & 1317 & 8003 & 8571 \\
\hline 1st 1998 & 464 & 6612 & 829 & 6613 & 5298 \\
\hline
\end{tabular}

* Volumes starting in October, 1997, may need to be further corrected in the future as our new production reporting system is quality-controlled and allocations reviewed.

\section{Monitor Project Performance}

As the $\mathrm{CO}_{2}$ project progressed this year, several key problem areas were identified for resolution. These problem areas can be summarized as : (1) high reservoir pressure, (2) narrow margin between reservoir pressure and parting pressure, and (3) out-of-zone injection problems.

The reservoir pressure in the project area is estimated at 2300 pounds per square inch gauged (psig), with much higher pressures to the north in the Emmons Unit (estimated at $2600 \mathrm{psig}$ ), and lower pressures to the south along the project area boundary. For this reason, the $\mathrm{CO}_{2}$ preferentially is traveling to the south of the horizontal Well No. 7C- $11 \mathrm{H}$, with initial oil response and $\mathrm{CO}_{2}$ breakthrough occurring primarily in that region. The project team is currently reviewing various alternatives for moving produced water off-lease for disposal outside of the Project area, in an effort to reduce overall system pressures. The reduction of overall reservoir pressure will also increase the efficiency of the injected $\mathrm{CO}_{2}$, as the same amount of $\mathrm{CO}_{2}$ will occupy more space, thus contact more oil under lower pressures.

Instantaneous shut-down pressure (ISDP) data obtained from the wellwork during second and third quarters in both the Emmons Unit and South Cowden Unit indicates the frac gradient to be approximately $.6 \mathrm{psi} / \mathrm{ft}$. With this knowledge the team recommended that the surface injection pressures for the water injection wells be limited to 650 psig for any water injection within the project area, and 1150 psig for $\mathrm{CO}_{2}$ injection. This would necessarily reduce the amount of $\mathrm{CO}_{2}$ being purchased, as well as injected, but would better insure the purchased $\mathrm{CO}_{2}$ was in fact being 
efficiently utilized. For the time being, the water injection wells surrounding the project area would be allowed to exceed these recommended injection pressures to dispose of excess water in the lower zones.

The field personnel implemented the above recommendations, which reduced considerably the amount of purchased gas required. However, it also changed the mix of the injected $\mathrm{CO}_{2}$ with the contaminated produced gas, thus the fluid head and resulting maximum surface injection pressures. Pressure surveys with gradient stops are planned for January in order to determine guideline pressures under current mixing conditions. As a result of the changes, the purchased $\mathrm{CO}_{2}$ volumes were reduced to minimum contract quantities of approximately $5 \mathrm{MMscfd}$, primarily being injected in the horizontal injection Wells Nos. 6C-25H and 7C-11H.

The out-of-zone injection problem is also believed to be exacerbated by the high reservoir pressure; for this reason, further conformance control work, including foamed cement squeezes and monomer/polymer work will be delayed until after the reservoir pressure has been reduced by a couple of hundred pounds.

TASK VI TECHNOLOGY TRANSFER, REPORTING, AND PROJECT MANAGEMENT

\section{$\underline{\text { Technology Transfer }}$}

Kimberly B. Dollens participated as a panelist and presenter in the $1997 \mathrm{SPE} \mathrm{CO}_{2}$ Conference (Dec. 10-11, 1997) in Midland, Texas. The conference focused on actual case histories. The talk was entitled "Application of Horizontal Injection Wells in the South Cowden Unit $\mathrm{CO}_{2}$ Flood". She also participated as a presenter in the 1998 Permian Basin Recovery Conference in Midland, Texas, on Thursday, March 26, 1998.

Kimberly B. Dollens submitted an abstract for a paper entitled "Field Implementation of a $\mathrm{CO}_{2}$ Flood in a Small Waterflood-Depleted Carbonate Unit," for presentation at the 1998 Southwestern Petroleum Short Course in Lubbock, Texas, April 8-9, 1997. The proposed paper will be co-authored by Ms. Dollens, Ken J. Harpole, and Larry Hallenbeck.

An abstract was submitted by T. F. McCoy, K. J. Harpole, and K. B. Dollens to the selection committee for the SPE Sixth International Oil and Gas Conference and Exhibition in Beijing, China, on November 2-6, 1998. The abstract is entitled "Transient Test Analysis Case History for Two Horizontal Miscible Gas Injection Wells".

A poster session entitled " Reservoir Characterization of an Upper Permian Platform Carbonate in Preparation for a Horizontal-Well $\mathrm{CO}_{2}$ Flood, South Cowden Unit, West Texas" was presented by Craig Caldwell and Kimberly B. Dollens at the Permian Basin Section of the Society of Economic Paleontologists and Mineralogists' (SEPM) Permian Basin Core Workshop in Midland, Texas, on Thursday, February 26, 1998. 